\title{
Characteristics of fricatives consonants orthography in Brazilian children
}

\section{Características da ortografia de consoantes fricativas na escrita infantil}

\author{
Larissa Paschoal', Isabela de Oliveira Pezarini', Suellen Vaz', Lourenço Chacon ${ }^{1}$
}

\begin{abstract}
Purpose: (1) describe children's orthographic performance in the record of fricative consonants in a position of simple syllabic attack; (2) verify the influence of the accent in errors occurrence; and (3) categorize the kind of errors found. Methods: Fifteen children's text productions were selected, they attended the First grade of Primary School in 2001, referred to 14 thematic proposals. From these productions, all the words with occurrence of fricative consonants in syllabic position of simple attack were selected. These occurrences were distributed in hits and errors, these were, then, organized according to the appearance in pre-tonic, tonic and post-tonic syllables, unstressed monosyllables and tonic monosyllables. Results: It was noted that (1) a predominance of hits compared to the errors; (2) the non-relevance of the accent in the record of unconventional fricatives; (3) higher occurrence of phonological substitutions, followed by the orthographical ones and, finally, in lower number, omissions; (40 predominance of errors inside the fricative phonological class. Conclusion: The group of children studied, even in the beginning of literacy, already shows very stable in the record of graphemes that is sent to the fricative phonemes. At last, it was observed that the errors seems to be motivated, mainly, by the difficulty of these children with the spelling of $\mathrm{PB}$.
\end{abstract}

Keywords: Handwriting; Language development; Child; Phonetics; Linguistics

\section{RESUMO}

Objetivos: (1) descrever o desempenho ortográfico de crianças no registro das consoantes fricativas em posição de ataque silábico simples;

(2) verificar a influência do acento na ocorrência de erros; (3) categorizar a tipologia dos erros encontrados. Métodos: Foram selecionadas produções textuais de 15 crianças, que cursaram a $1^{\text {a }}$ série do Ensino Fundamental no ano de 2001, referentes a 14 propostas temáticas. Dessas produções, foram selecionadas todas as palavras com ocorrência de consoantes fricativas em posição silábica de ataque simples. Essas ocorrências foram distribuídas em acertos e erros, organizados conforme aparecessem em sílabas pretônicas, tônicas, postônicas, monossílabos átonos e monossílabos tônicos. Resultados: Observou-se (1) predomínio de acertos em relação a erros; (2) não relevância do acento no registro não convencional das fricativas; (3) maior ocorrência de substituições fonológicas, seguidas de ortográficas e, em menor número, omissões; (4) predomínio de erros dentro da classe fonológica das fricativas. Conclusão: $\mathrm{O}$ grupo de crianças estudado, ainda que em início de alfabetização, já se mostra bastante estável no registro dos grafemas que remetem aos fonemas fricativos. Observou-se que o erro parece ser motivado, principalmente, pela dificuldade dessas crianças com as convenções ortográficas do Português Brasileiro.

Descritores: Escrita manual; Desenvolvimento da linguagem; Criança; Fonética; Linguística

Work accomplished in the Speech Therapy Course, College of Philosophy and Sciences, Universidade Estadual Paulista "Júlio de Mesquita Filho" - UNESP — Marília (SP), Brazil.

(1) Speech Therapy Course, College of Philosophy and Sciences, Universidade Estadual Paulista "Júlio de Mesquita Filho" - UNESP - Marília (SP) Brazil. Conflict of interests: No

Authors' contribution: $L P$ main researcher, research development, chronogram development, literature survey, data collection and analysis, article writing, submission and channels of the article; $I O P$ researcher, literature survey, data collection and analysis, article writing; $S V$ researcher, literature survey, data collection and analysis, article writing; $L C$ advisor, research coordination, data analysis, article writing correction, final version approval.

Correspondence address: Larissa Paschoal. R. Bélgica, 1442, Parque Paraíso, Itapecerica da Serra (SP), Brazil, CEP: 06852-180.

E-mail: larissa.apaschoal@gmail.com

Received on: 7/10/2014; Accepted on: 10/28/2014 


\section{INTRODUCTION}

In recent years, in studies which involve the written acquisition, both in the national literature and in the international one, it is noted the concern to investigate the orthographic performance of children in reading, written and phonological awareness activities ${ }^{(1-6)}$. It is also noted, the concern with the misspellings, characterized not only by the type of errors, but also by the way the written process is developed ${ }^{(7-9)}$. Moreover, it is observed the concern with the efficiency of therapeutic programs which aim the improvement of students performance, focused on the tasks that involve the codification and decoding of spelling characters in the written and reading ${ }^{(10,11)}$. It is finally checked the care with the aspects of authorship in the written ${ }^{(12)}$ and with the errors analysis considered as pathological in the children written ${ }^{(13)}$.

However, it is realized in these studies few reference to the relation among orthography and phonetic-phonological aspects of language. Nevertheless, these relations have been investigated by the Group of Research "Studies about the acquisition of written language" (GEALE/CNPq) ${ }^{(14-16)}$ and by the Group of Research "Studies about Language" (GPEL/CNPq) ${ }^{(17-24)}$.

In consonance with the investigations carried out in both groups, the research that resulted in this article searched to investigate the relation among phonetic-phonological and orthographic aspects of language, more specifically in the registration of fricative consonant of the Brazilian Portuguese (BP), in children in the beginning of written acquisition.

The investigation of this relation was guided by the following objectives: (1) to describe the orthographic performance of children in the registration of fricative consonant in position of simple syllabic attack; (2) to check the possible influence of the accent in the occurrence of errors and (3) to categorize the typology of the errors found.

\section{METHODS}

The investigation was approved by the Ethics Committee in Research of the College of Philosophy and Sciences of the Universidade Estadual Paulista "Júlio de Mesquita Filho" (UNESP) under the number 0132/2010.

\section{Data}

The data used are part of a database composed of textual productions of children from $1^{\text {st }}$ to $4^{\text {th }}$ grade, who attended Elementary School (ES) in the period 2001-2004, in two public schools in the countryside of São Paulo. These productions were collected by researchers who every 15 days or so, presented different thematic proposals, on which the children should write a text. The productions were made by children who had neither complaint about learning nor by language development, according to information provided by their teachers. The ones responsible for the children signed the Term of Free and Clear Consent, which authorized the participation in the research.

Out of this database, it was made a cutout for the present study, in which they were selected 15 textual productions of children who attended the 1st grade of ES in 2001, in one of the two schools. These children were selected for being the ones who remained enrolled in the school during the four years of the data collection. Throughout the school year, 14 different thematic proposals were scheduled. Therefore, it was expected for the analysis, a total of 210 textual productions (15 children x 14 proposals). However, out of these 210, only 175 were analyzed due to the absences of children in certain proposals and the impossibility of interpreting the writing of some children.

\section{Data Analysis}

The fricative consonants were analyzed only in the position of simple syllabic attack. The analysis of the results was accomplished in consonance with the objectives of this investigation. Thus, according to the first objective (to describe the orthographic performance in the fricative consonants), the registrations of these consonants were divided in hits, when the written of the fricative consonant obeyed the orthographic conventions of the Brazilian Portuguese (BP) and errors, when the written of the fricative consonant did not obey the orthographic conventions of the BP.

According to the second objective (to check the possible influence of the accent in the occurrence of errors), the errors were distributed as they appeared in accented syllables - stressed and stressed monosyllables - and unaccented syllables - unstressed, unstressed monosyllables and posttonics.

Finally, according to the third objective (to check the types of errors due to the accent), both in the accentedd syllables and in the unaccented ones, the errors were subdivided into three categories: (a) omissions - when there was no registration of the fricative consonant, as for example, in the word "casal", registered as "caal"; (b) orthographic substitutions - when the child made a substitution which did not change the phonological value of the word, as for example, in the word "caçador", registered as "cassador"; (c) phonological substitutions - when the child made a substitution which changed the phonological value of the word, as for example, the word "faca", registered as "vaca".

Also in relation to the third objective, the phonological substitutions were, in turn, subdivided in "inside the class" (IC)- when the substitution occurred among graphemes which referred to phonemes of the fricative class - and "out of the class" (OC) - when the substitution occurred among graphemes which referred to phonemes from other classes, other than the fricatives ones.

\section{Statistical analysis}

The statistical treatment of data was accomplished, with 
the use of the software Statistica (version 7.0). Descriptive and inferential analyzes were accomplished. To the analysis of the data related to all the objectives, the parametric test T-test was used to dependent variables. To the analysis of the third objective it was used the test nonparametric Friedman ANOVA and Kendall Coeff of concordance to dependent variables. It was considered as significant $\alpha \leq 0,05$.

\section{RESULTS}

To a better exposure, the results will be described according to the research objectives.

Regarding the first objective, 2.374 possibilities of registration of fricative consonants were found, been observed therefore predominance of hits in the registration of such consonants. The values are exposed in Figure 1 and in the Table 1.

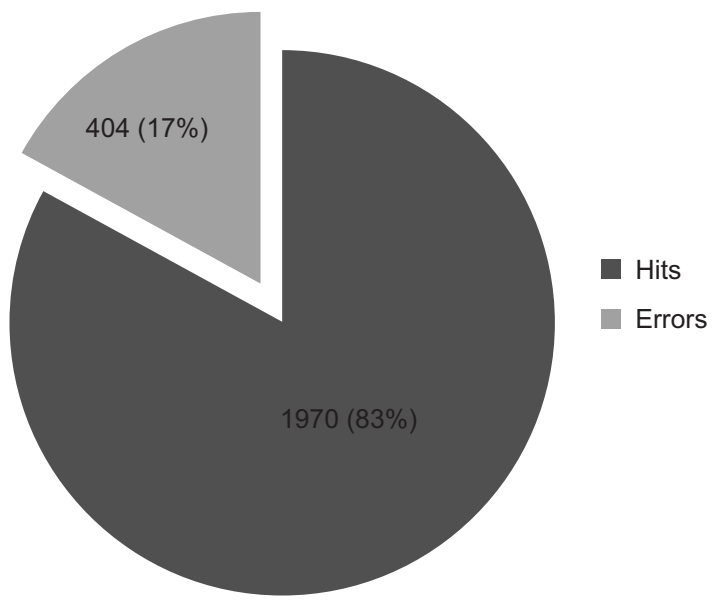

Figura 1. Distribution of graphic registers in hits and errors

Table 1. Distribution of occurrences in hits and errors

\begin{tabular}{lccc}
\hline Accuracy & Mean & Standard deviation & T-test \\
\hline Hits & 140.71 & 86.52 & $\mathrm{t}=5.22$ \\
Errors & 28.86 & 14.65 & $\mathrm{p}=0.00$ \\
& & & $\mathrm{df}=13$ \\
\hline
\end{tabular}

T-test to dependent variables $(\alpha \leq 0.05)$

About the second objective, the total of errors was distributed into accented and unaccented syllables, according to its occurrence. The presence/absence of the accent did not interfere in the non conventional registration of such consonants. The values found are exposed in Figure 2 and in Table 2.

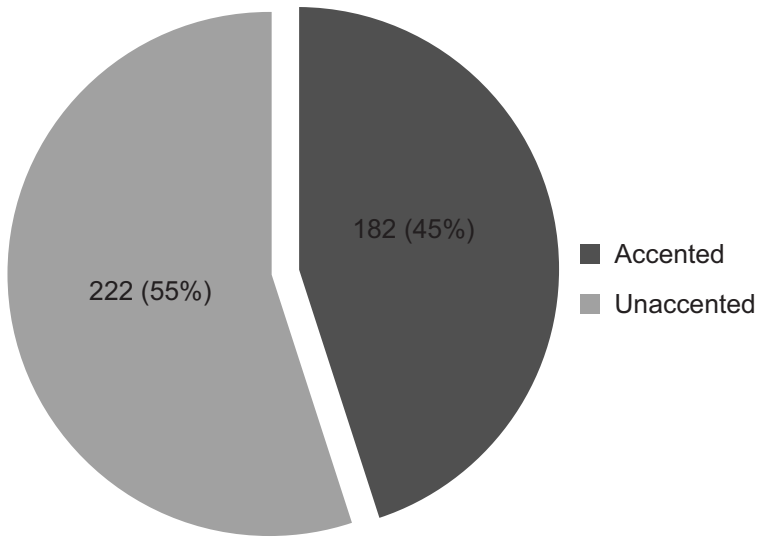

Figure 2. Distribution of errors in accented and unaccented syllables

Table 2. Errors in accented and unaccented syllables

\begin{tabular}{lccc}
\hline Accuracy & Mean & $\begin{array}{c}\text { Standard } \\
\text { deviation }\end{array}$ & T-test \\
\hline Accented syllables & 13 & 6.92 & $\mathrm{p}=0.09$ \\
Unaccented syllables & 15.86 & 8.81 & $\mathrm{t}=1.77$ \\
& & & $\mathrm{df}=13$ \\
\hline
\end{tabular}

T-test to dependent variables $(\alpha \leq 0.05)$

Regarding the third objective, it is observed that the occurrence of phonological substitutions, in spite of being in greater number, was close to the occurrence of orthographic substitutions. On the other side the occurrence of omissions, when compared to the one of two types of substitutions showed great difference to less (Table 3).

Here follows examples of these three types of errors:

a)

CAPESA - it is about the phonological substitution, because the presence of the grapheme $\{s\}$ where it would be expected the grapheme $\{c\}$ leads to a reading of the word as /ka'beza/;

b) DE $/ C$ HA - it is about orthographic substitution, because the non conventional presence of $\{\mathrm{ch}\}$ where it would be expected $\{\mathrm{x}\}$ does not change the phonological value of the word in a possible reading of it.

c) FEL I DADS -it is about omission of the grapheme $\{c\}$ in the syllable "CI" of the word "felicidades"

Also with respect to the third objective, it is observed the

Table 3. Distribution of orthographic substitutions, phonological substitutions and omissions

\begin{tabular}{lccccc}
\hline Accuracy & Total & Mean & Standard deviation & $\begin{array}{c}\text { Friedman ANOVA } \\
\text { and Kendall Coeff } \\
\text { of concordance }\end{array}$ \\
\hline Phonological substitution & $211(52.23 \%)$ & 15.07 & 9.86 & ANOVA=21.92 & 36 \\
Orthographic substitution & $179(44.31 \%)$ & 12.78 & 6.63 & $\mathrm{p}=0.00$ & 34 \\
Omission & $14(3.47 \%)$ & 1 & 1.57 & $\mathrm{df}=2 \quad 14$ \\
\hline
\end{tabular}

Friedman ANOVA and Kendall Coeff of concordance $(\alpha \leq 0.05)$ 
Table 4. Distribution phonological substitutions wihtin and out of the fricative phonological class

\begin{tabular}{lcccc}
\hline Accuracy & Total & Mean & Standard deviation & T-test \\
\hline Inside the class & $192(88.89 \%)$ & 13.71 & 9.26 & $\mathrm{p}=0.00$ \\
Out of the class & $24(11.11 \%)$ & 1.71 & 1.54 & $\mathrm{t}=5.07$ \\
& & & & $\mathrm{df}=13$ \\
\hline
\end{tabular}

T-test to dependent variables $(\alpha \leq 0.05)$

predominance of phonological replacements inside the class of the fricative ones (Table 4)

The following are examples of these substitutions:

a) $F O C \mathbb{E}_{-}$it is concerned, in this occurrence the writing of the word "você" with the grapheme $\{f\}$ instead of the $\{\mathrm{v}\}$ one. The presence of this grapheme causes, in a possible reading of the word a substitution of the phoneme $/ \mathrm{v} /$ by the /f/ one, both from the class of the fricative ones, in other words, it is about the substitution IC;

b) LHAMA - on the other side in this occurrence it is concerned the substitution of the grapheme $\{\mathrm{ch}\}$ by the $\{\mathrm{lh}\}$ one in the word "chama". This substitution makes the reading of the word show a sounding consonant phoneme, instead of a (expected) fricative one. It is about then replacement OC.

\section{DISCUSSION}

Regarding the first objective (to describe the orthographic performance of children in the registration of the fricative consonants) it was observed greater occurrence of hits than of errors. This result suggests that, even in the beginning of literacy, the group of children studied presented notable stability in the registration of the fricative consonants, what also indicates the efficiency of the literacy practices on which these children found themselves inserted in their literacy. This stability is not pointed out in the studies which analyzed the children orthography. Indeed, even considering the relation among hits and errors, the investigations reported in these studies turned themselves, preferably, to the characterization of the orthographic performance of children by the analysis of their errors and not by their general orthographic performance (hits $\mathrm{x}$ errors) $)^{(7-9)}$.

Regarding the second objective (to check the possible influence of the accent in the occurrence of errors), this influence did not show itself relevant in the non-conventional registration of the graphemes which refer to the fricative phonemes. It is suggested then that the investigated children did not base only in the phonetic aspects of the language when producing their writing, but also in aspects related to literacy, as for example the pedagogical work with the correspondence phoneme/grapheme. In another study ${ }^{(20)}$, on which they were investigated omissions of graphemes in the whole syllable or in part of it and, yet, if these omissions occurred, preferably, in accented syllables or in unaccented ones, it was observed that the accent did not show itself as relevant variable in the omission of the syllable as a whole. However, it showed itself relevant in the omission of part of the syllable. This disparity suggests then the non-relevance of the accent in phenomena of the writing acquisition, given the instability of its action on the infant orthography. Therefore, the "written product of children anchors itself not only in what they speak and listen, but also in what they write and read fact which demonstrates the importance that (also) the visual aspects of the writing have for the children"(20).

Regarding the third objective (to categorize the typology of errors), the most frequent type was the phonological substitution, followed by the orthographic substitution and finally, in a lower number, by the omission, with relevant difference only among the last one and the others. The highest amount of phonological and orthographic replacements can be founded by the predominance of the opacity in the writing of phonemes of the fricative class in the BP, once this opacity shows itself in four of its six phonemes. Indeed, a same grapheme can, in certain syllabic positions, represent distinct phonemes, or the contrary, a same phoneme can present more than one possibility of graphic representation. Thus, it is suggested that the error is motivated, above all, by the difficulty of the children with the orthographic complexity of the BP. Finally the low number of omissions suggests that, although they do not have domain of the orthography, these children, somehow, comprehended the syllable structure, with tendency to register each one of its essential positions, in other words, the attack and the nucleus, by a grapheme.

Still regarding the third objective, the phonological substitutions occurred in greater number in the subcategory "inside the class", when compared to the subcategory "out of the class". This result suggests that the children realized phonetic-phonological differences among the consonantal classes, as well as differences among the several ways to spell the fricative phonemes. However, the error did not occur at random. This result also suggests that the error was motivated, mainly, by the difficulty of children with orthographic aspects of these phonemes, in other words, with the domain of the context in which certain grapheme can, or not, be used.

\section{CONCLUSION}

The group of children studied, in spite of being in the beginning of literacy, is already very stable in the registration of the graphemes which refer to the fricative phonemes. 
Regarding the errors, it was observed that they do not suffer influence of the accent, which seems to be an unstable variable in phenomena of the writing acquisition. It was also observed that the error can be motivated, mainly, by the difficulty of those children with the orthographic conventions of the BP.

The investigation reported in this work can contribute to the understanding of the orthographical difficulties in the beginning of literacy, inside a same phonological class.

\section{ACKNOWLEDGMENTS}

To the Conselho Nacional de Desenvolvimento Científico e Tecnológico (CNPq), process 305206/2013-3 and to the Fundação de Amparo à Pesquisa do Estado de São Paulo (FAPESP), process 2013/13814-6), for the financing granted to the accomplishment of the research whose results were reported in this work.

\section{REFERENCES}

1. Paolucci JF, Ávila CRB. Competência ortográfica e metafonológica: influências e correlações na leitura e escrita de escolares da $4^{\circ}$ série. Rev Soc Bras Fonoaudiol. 2009;14(1):48-55.

2. Nunes C, Frota S, Mousinho R. Consciência fonológica e o processo de aprendizagem de leitura e escrita: implicações teóricas para o embasamento da prática fonoaudiológica. Rev CEFAC. 2009;11(2):20712. http://dx.doi.org/10.1590/S1516-18462009000200005

3. Ferreira F, Correa J. Consciência metalinguística e a representação da nasalização na escrita do Português Brasileiro. Rev CEFAC. 2010;12(1):40-50. http://dx.doi.org/10.1590/S1516-18462010000100006

4. Pontes VL, Diniz NLF, Martins-Reis VO. Parâmetros e estratégias de leitura e escrita utilizados por crianças de escolas pública e privada. Rev CEFAC. 2013;15(4):827-36. http://dx.doi.org/10.1590/S151618462013000400011

5. Furnes B, Samuelson S. Preschool cognitive and language skills predicting Kindergarten and Grade 1 reading and spelling: a crosslinguistic comparison. J Res Read. 2009;32(3):275-92. http://dx.doi. org/10.1111/j.1467-9817.2009.01393.x

6. Furnes B, Samuelson S. Predicting reading and spelling difficulties in transparent and opaque orthographies: a comparison between scandinavian and US/Australian Children. Dyslexia. 2010;16(2):119-42. http://dx.doi.org/10.1002/dys.401

7. Capellini SA, Amaral AC, Oliveira AB, Sampaio MN, Fusco N, Cervera-Mérida JF et al. Desempenho ortográfico de escolares do $2^{\circ}$ ao $5^{\circ}$ ano do ensino público. J Soc Bras Fonoaudiol. 2011;23(3):227-36. http:// dx.doi.org/10.1590/S2179-64912011000300008

8. Rosa CC, Gomes E, Pedroso FS. Aquisição do sistema ortográfico: desempenho na expressão escrita e classificação dos erros ortográficos. Rev CEFAC. 2012;14(1):39-45. http://dx.doi.org/10.1590/S151618462011005000087

9. Capellini SA, Romero ACL, Oliveira AB, Sampaio MN, Fusco N,
Cervera-Mérida, JF et al. Desempenho ortográfico de escolares do $2^{\circ}$ ao $5^{\circ}$ ano do ensino particular. Rev CEFAC. 2012;14(2):254-67. http:// dx.doi.org/10.1590/S1516-18462012005000012

10. Brito CLR, Uzêda CPQ, Vieira JG, Cavalheiro LG. Habilidades de letramento após intervenção fonoaudiológica em crianças do $1^{\circ}$ ano do ensino fundamental. Rev Soc Bras Fonoaudiol. 2010;15(1):88-95. http:// dx.doi.org/10.1590/S1516-80342010000100015

11. Cárnio MS, Pereira MB, Alves DC, Andrade RV. Letramento escolar de estudantes de $1^{\mathrm{a}}$ e $2^{\mathrm{a}}$ séries do ensino fundamental de escola pública. Rev Soc Bras Fonoaudiol. 2011;16(1):1-8. http://dx.doi.org/10.1590/ S1516-80342011000100003.

12. Machado MLCA, Berberian AP, Santana AP. Linguagem escrita e subjetividade: implicações do trabalho grupal. Revista CEFAC. 2009;11(4):713-9. http://dx.doi.org/10.1590/S1516-18462009000800022 13. Massi G, Signor R, Berberian AP, Munhoz CMA, Guarinello AC, Krüger $\mathrm{S}$ et al. A análise de elementos de referenciação em textos produzidos por sujeitos em processo de apropriação da escrita. Distúrb Comunic. 2009;21(2):169-78.

14. Adamoli MA, Miranda ARM. Do conhecimento fonológico ao conhecimento ortográfico: as diferentes grafias dos ditongos orais mediais ai e ei em textos de escrita inicial. Cad Pesq Linguíst. 2009;4:232-55.

15. Miranda ARM, Matzenauer CLB. Aquisição da fala e da escrita: relações com a fonologia. Cad Educ. 2010;(35):359-405.

16. Teixeira SM, Grassi LH, Oliveira ND, Miranda ARM. Uma reflexão acerca do erro ortográfico: a importância do conhecimento sobre a língua para a prática pedagógica de professores das séries iniciais. Verba Volant. 2011;2:78-94.

17. Chacon L. Para além de vínculos diretos entre características fonético-segmentais e ortográficas na escrita infantil. Rev Est Linguag. 2008;16(1):215-30.

18. Cardoso MH, Rodrigues LL, Freitas MCC, Chacon L. A complexidade da coda silábica na escrita de pré-escolares. Distúrb. Comunic. 2010;22(3):213-21.

19. Berti LC, Chacon L, Santos AP. A escrita de /aN/ por pré-escolares: pistas acústico-auditivas. Cad Educ (Pelotas). 2010;(35):195-291.

20. Chacon L, Berti LC, Burgemeister A. Ortografia da nasalidade em ataque e coda silábica na escrita infantil: características fonéticas e fonológicas. Verba Volant, 2011;2(1):1-21.

21. Amaral AS, Freitas MCC, Chacon L, Rodrigues LL et al. Omissão de grafemas e características da sílaba na escrita infantil. Revista CEFAC. 2011;13(5):846-55. http://dx.doi.org/10.1590/S151618462011005000007

22. Tenani LE, Reis MC. "E veveram felizes para sempre": análise de grafias não-convencionais de vogais pretônicas. Verba Volant. 2011;2(1):22-43.

23. Schier AC, Berti LC, Chacon L. Desempenho perceptual-auditivo e ortográfico de consoantes fricativas na aquisição da escrita. CoDAS. 2013;25(1):45-51. http://dx.doi.org/10.1590/S2317-17822013000100009 24. Chacon L, Vaz S. Relações entre aquisição da percepção auditiva e aprendizagem da ortografia: consoantes soantes em questão. Ling (Dis)curso. 2013;13(3):695-719. http://dx.doi.org/10.1590/S151876322013000300010 